\title{
Social and Economic Rights? Lessons from South Africa
}

\section{Citation}

Cass R. Sunstein, Social and Economic Rights? Lessons from South Africa (John M. Olin Program in L. \& Econ., Working Paper No. 124, 2001).

\section{Published Version}

http://chicagounbound.uchicago.edu/law_and_economics/455/

\section{Permanent link}

http://nrs.harvard.edu/urn-3:HUL.InstRepos:12785996

\section{Terms of Use}

This article was downloaded from Harvard University's DASH repository, and is made available under the terms and conditions applicable to Other Posted Material, as set forth at http:// nrs.harvard.edu/urn-3:HUL.InstRepos:dash.current.terms-of-use\#LAA

\section{Share Your Story}

The Harvard community has made this article openly available.

Please share how this access benefits you. Submit a story.

Accessibility 


\section{University of Chicago Law School Chicago Unbound}

Coase-Sandor Working Paper Series in Law and

Economics

Coase-Sandor Institute for Law and Economics

2001

\section{Social and Economic Rights? Lessons from South Africa}

Cass R. Sunstein

Follow this and additional works at: http://chicagounbound.uchicago.edu/law_and_economics Part of the Law Commons

\section{Recommended Citation}

Cass R. Sunstein, "Social and Economic Rights? Lessons from South Africa" (John M. Olin Program in Law and Economics Working Paper No. 124, 2001).

This Working Paper is brought to you for free and open access by the Coase-Sandor Institute for Law and Economics at Chicago Unbound. It has been accepted for inclusion in Coase-Sandor Working Paper Series in Law and Economics by an authorized administrator of Chicago Unbound. For more information, please contact unbound@law.uchicago.edu. 


\section{CHICAGO}

John M. Olin LAW \& ECONOMics WORKING PAPER No. 124

(2D SERIES)

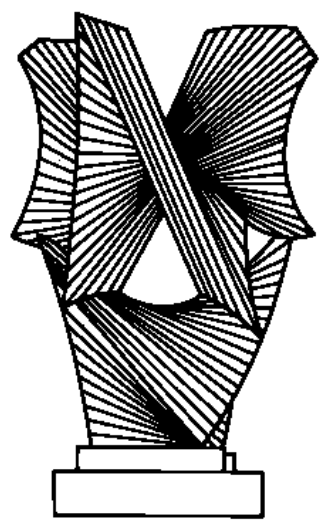

\section{SOCIAL AND ECONOMIC RIGHTS? LESSONS FROM SOUTH AFriCA}

\section{CASS R. Sunstein}

The Law School

The University of Chicago

This paper can be downloaded without charge at:

The Chicago Working Paper Series Index:

http:/www.law.uchicago.edu/Lawecon/index.html

The Social Science Research Network Electronic Paper Collection:

http://papers.ssrn.com/paper.taf?abstract_id=269657 
Preliminary draft 3/7/01

All rights reserved

\section{Social and Economic Rights? Lessons from South Africa}

\section{Cass R. Sunstein*}

\section{Introduction}

Here is one of the central differences between late eighteenth century constitutions and late twentieth century constitutions: The former make no mention of rights to food, shelter, and health care, whereas the latter tend to protect those rights in the most explicit terms. A remarkable feature of international opinion - firmly rejected in the United States - is that socio-economic rights deserve constitutional protection.

But should a democratic constitution really protect the right to food, shelter, and medical care? Do "socio-economic" rights of this sort belong in a Constitution? What do they have to do with citizenship? Do they promote or undermine democratic deliberation? If such rights are created, what is the role of the courts?

My aim in this Essay is to shed light on these questions, largely by discussing an extraordinary decision by the Constitutional Court of South Africa, one that carries some significant lessons for the future. ${ }^{1}$ In the Grootboom decision, the Court set out a novel and promising approach to judicial protection of socio-economic rights. This approach requires close attention to the human interests at stake, and sensible priority-setting, but without mandating protection for each person whose socio-economic needs are at risk. The distinctive virtue of the Court's approach is that it is respectful of democratic prerogatives and of the limited nature of public resources, while also requiring special deliberative attention to those whose minimal needs are not being met. The approach of the Constitutional Court stands as a powerful rejoinder to those who have contended that socio-economic rights do not belong in a constitution. It suggests that such rights can serve, not to preempt democratic deliberation, but to ensure democratic attention to important interests that might otherwise be neglected in ordinary debate. It also illuminates the idea, emphasized by the Court itself, that all rights, including the most conventional and uncontroversial, impose costs that must be borne by taxpayers.

To be sure, it is far too early to say whether the Court's approach can fully accommodate the concerns of those who object to judicial protection of socio-economic rights. But for the first time in the history of the world, a constitutional court has initiated a process that might well succeed in the endeavor of ensuring that protection without placing courts in an unacceptable managerial role. This point has large implications for how we think about citizenship, democracy, and minimal social and economic needs.

\footnotetext{
* Karl N. Llewellyn Distinguished Service Professor of Jurisprudence, University of Chicago, Law School and Department of Political Science. A different version of this essay will appear as a chapter in Cass R. Sunstein, Designing Democracy: What Constitutions Do (forthcoming 2001).

${ }^{1}$ Government of the Republic of South Africa v. Grootboom, 11 BCLR 1169 (CC) (2000).
} 


\section{A. A Debate and A Resolution}

1. In general. For many years, there has been a debate about whether social and economic rights, sometimes known as socio-economic rights, belong in a constitution. $^{2}$ The debate has occurred with special intensity in both Eastern Europe and South Africa. Of course the American Constitution, and most constitutions before the twentieth-century, protected such rights as free speech, religious liberty, and sanctity of the home, without creating rights to minimally decent conditions of life. But in the late twentieth century, the trend is otherwise, with international documents, and most constitutions, creating rights to food, shelter, and more.

Some skeptics have doubted whether such rights make sense from the standpoint of constitutional design. On one view, a constitution should protect "negative" rights, not "positive" rights. Constitutional rights should be seen as individual protections against the aggressive state, not as private entitlements to protection by the state. For people who share this view, a constitution is best understood as a bulwark of liberty, properly conceived; and a constitution that protects "positive" rights can be no such bulwark, because it requires government action, rather than creating a wall of immunity around individual citizens.

But there are many problems with this view. Even conventional individual rights, like the right to free speech and private property, require governmental action. Private property cannot exist without a governmental apparatus, ready and able to secure people's holdings as such. So-called negative rights are emphatically positive rights. In fact all rights, even the most conventional, have costs. ${ }^{3}$ Rights of property and contract, as well as rights of free speech and religious liberty, need significant taxpayer support. In any case we might well think that the abusive or oppressive exercise of government power consists, not only in locking people up against their will, or in stopping them from speaking, but also in producing a situation in which people's minimal needs are not met. Indeed, protection of such needs might be seen as part of the necessary wall of immunity, and hardly as inconsistent with it.

If the central concerns are citizenship and democracy, the line between negative rights and positive rights is hard to maintain. The right to constitutional protection of private property has a strong democratic justification: If people's holdings are subject to ongoing governmental adjustment, people cannot have the security, and independence, that the status of citizenship requires. The right to private property should not be seen as an effort to protect wealthy people; it helps ensure deliberative democracy itself. But the same things can be said for minimal protections against starvation, homelessless, and other extreme deprivation. For people to be able to act as citizens, and to be able to count

\footnotetext{
${ }^{2}$ Seee, e.g., Scott, Constitutional Ropes of Sand or Justiciable Guarantees?, 141 U Pa L Rev 1 (1992); Symposium, Socio-economic Rights, 8 SAJHR 451 (1992).

${ }^{3}$ See Stephen Holmes and Cass R. Sunstein, The Cost of Rights (1999).
} 
themselves as such, they must have the kind of independence that such minimal protections ensure.

On the other hand, a democratic constitution does not protect every right and interest that should be protected in a decent or just society. Perhaps ordinary politics can be trusted; if so, there is no need for constitutional protection. The basic reason for constitutional guarantees is to respond to problems faced in ordinary political life. If minimal socio-economic rights will be protected democratically, why involve the Constitution? The best answer is that to doubt the assumption and to insist such rights are indeed at systematic risk in political life, especially because those who would benefit from them lack political power. It is not clear if this is true in every nation. But certainly it is true in many places.

Perhaps more interestingly, critics of socio-economic rights have made a point about democratic institutions. In particular, they have argued that socio-economic rights are beyond judicial capacities. ${ }^{4}$ On this view, courts lack the tools to enforce such guarantees. If they attempt to do so, they will find themselves in an impossible managerial position, one that might discredit the constitutional enterprise as a whole. How can courts possibly oversee budget-setting priorities? If a state provides too little help to those who seek housing, maybe it is because the state is concentrating on the provision of employment, or on public health programs, or on educating children. Is a court supposed to oversee the full range of government programs, to ensure that the state is placing emphasis on the right areas? How can a court possibly acquire the knowledge, or make the value judgments, that would enable it to do that? There is a separate point. A judicial effort to protect socio-economic rights might seem to compromise, or to preempt, democratic deliberation on crucial issues, because it will undermine the capacity of citizens to choose, in accordance with their own judgments, the kinds of welfare and employment programs that they favor. Of course some of these points hold for conventional rights as well. But perhaps social and economic rights are especially troublesome on this count, because they put courts in the position of overseeing largescale bureaucratic institutions.

It would be possible to respond to these institutional concerns in various ways. Perhaps constitutions should not include socio-economic rights at all. Perhaps such rights should be included, but on the explicit understanding that the legislature, and not the courts, will be entrusted with enforcement. Section IV of the Indian Constitution expressly follows this route, contained judicially unenforceable "directive principles" and attempting to encourage legislative attention to these rights without involving the judiciary.. [Could you mention the section(s) in the Indian Constitution?] The advantage of this approach is that it ensures that courts will not be entangled with administration of social programs. The disadvantage is that without judicial enforcement, there is a risk that the constitutional guarantees will be mere "parchment barriers," meaningless or empty in the real world.

\footnotetext{
${ }^{4}$ See Davis, The Case Against Inclusion of Socio-economic Rights in a Bill of Rights Except as Directive Principles, 8 SAJHR 475 (1992).
} 
2. The case of South Africa. The appropriate approach to socio-economic rights was intensely debated before ratification of the South African Constitution. ${ }^{5}$ The idea of including socio-economic rights was greatly spurred by international law, above all by the International Covenant on Economic, Social and Cultural Rights, to which I will return. Much of the debate involved the appropriate role of the judiciary. In part this was a relatively abstract debate, posing a concrete real-world issue but founded on a set of theoretical considerations just sketched, involving judicial capacities and the proper place, if any, of socio-economic rights in a democratic constitution. But aside from these points, the debate was greatly influenced by the particular legacy of apartheid and by claims about what to do about that legacy at the constitutional level. In the view of many of those involved in constitutional design, the apartheid system could not plausibly be separated from the problem of persistent social and economic deprivation. In the end the argument for socio-economic rights was irresistible, in large part because such guarantees seemed an indispensable way of expressing a commitment to overcome the legacy of apartheid - the overriding goal of the new Constitution.

We should emphasize a general point here about constitutionalism. ${ }^{6}$ Some constitutions are preservative; they seek to maintain existing practices, to ensure that things do not get worse. This is of course Edmund Burke's conception of the English constitution. By contrast, some constitutions are transformative; they set out certain aspirations that are emphatically understood as a challenge to longstanding practices. They are defined in opposition to those practices. The American constitution is a mixture of preservative and transformative features, with some provisions looking backward, and others very much looking forward. The South African constitution is the world's leading example of a transformative constitution. A great deal of the document is an effort to eliminate apartheid "root and branch." Constitutions are often described as precommitment strategies, designed to ensure against myopic or mistaken decisions in ordinary politics. ${ }^{7}$ If is it apt to describe the South African Constitution in these terms, this is because the document is designed to ensure that future governments do not fall prey to anything like the evils of the apartheid era. The creation of socio-economic rights is best understood in this light.

\section{B. A Continuing Debate}

But what, in particular, is the relationship among socio-economic rights, courts, and legislatures? The South African Constitution hardly speaks unambiguously on this topic. The rights in question typically take the following form, in an evident acknowledgement of limited resources:

1. Everyone has the right to [the relevant good].

2. The state must take reasonable legislative and other measures, within its available resources, to achieve the progressive realization of this right.

\footnotetext{
${ }^{5}$ See note 1 supra; see also Chaskalson et al., Constitutional Law of South Africa 41-3-41-4 (2000).

${ }^{6}$ See Lawrence Lessig, Code and Other Laws of Cyberspace (1999).

${ }^{7}$ See Stephen Holmes, Passions and Constraint (1995).
} 
This is the basic form of constitutional rights to "an environment that is not harmful to their health or well-being" (section 24); housing (section 26); and health, food, water, and social security (section 27).

A provision of this kind does not clearly create or disable judicial enforcement. On the basis of the text alone, it would be easy to imagine a judicial ruling to the effect that enforcement is reserved to nonjudicial actors within "the state." On this view, the South African Constitution is, with respect to judicial enforcement, closely akin to the Indian Constitution. But it would also be easy to imagine a ruling to the effect that courts are required to police the relevant rights, by ensuring that the state has, in fact, taken "reasonable legislative and other measures, within its available resources, to achieve progressive realization of this right." If, for example, the state has done little to provide people with decent food and health care, and if the state is financially able to do much more, it would seem that the state has violated the constitutional guarantee.

In certifying the Constitution, the South African Constitutional Court resolved this question in just this way, concluding that socio-economic rights are indeed subject to judicial enforcement. ${ }^{8}$ The Court said that such rights "are, at least to some extent, justiciable." The fact that resources would have to be expended on them was hardly decisive, for this was true of "many of the civil and political rights entrenched" in the Constitution. The Court correctly said that many rights, including so-called negative rights, "will give rise to similar budgetary implications without compromising their justiciability." But in a final sentence, the Court added new ambiguity, by suggesting that at "the very minimum, socio-economic rights can be protected negatively from improper invasion." This last sentence added considerable ambiguity, because it did not say whether and when courts could go beyond the "minimum" to protect rights "positively"; nor did it make entirely clear what it would mean to invade socio-economic rights "negatively." Perhaps the Court's suggestion was that when the state, or someone else, actually deprived someone of (for example) shelter, say by evicting them form the only available source of housing, judicial enforcement would be appropriate. But if this is what the Court meant, the socio-economic rights would be hardly justiciable at all; this would be an exceedingly narrow use of judicial authority in overseeing the relevant rights.

The ultimate outcome of the debate over judicial protection of socio-economic rights carries both particular and general interest. It is of particular interest in South Africa, where a substantial percentage of the population lives in desperate poverty. Does the Constitution do anything to help them? For example, might the judiciary play a role in ensuring that governmental priorities are set in the way that the Constitution apparently envisages? Or might judicial involvement in protecting socio-economic rights actually impair reasonable legislature efforts to set sensible priorities? The outcome has general interest because it should tell us a great deal about the social and democratic consequences, both good and bad, of constitutional provisions creating socio-economic rights. Thus far discussion of this issue has both highly speculative and uninformed by

\footnotetext{
${ }^{8}$ Ex Parte Chairperson of the Constittuonal Assembly, 1996 (4) SA 744, 1996 (10) BCLR 1243 (CC) at para 78.
} 
actual practice. ${ }^{9}$ The South African experience will inevitably provide a great deal of information.

The Constitutional Court has now rendered its first major decision involving these rights, in a case involving the right to shelter. It is to that case that I now turn.

\section{The Background}

\section{A. The Housing Shortage and the Apartheid Legacy}

It is impossible to understand the South African dispute over the right to shelter, or the proceedings in the Constitutional Court, without reference to the effects of apartheid. The central point is that in the view of most observers, the system of apartheid is directly responsible for the acute housing shortage in many areas of the nation.

One of the central components of apartheid was a system of "influx control" that sharply limited African occupation of urban areas. ${ }^{10}$ In the Western Cape, the government attempted to exclude all African people and to give preference to the colored community. The result was to freeze the provision of housing for African people on the Cape Peninsula in 1962. Nonetheless, African people continued to move into the area in search of jobs. Lacking formal housing, large numbers of them moved into "informal settlements," consisting of shacks and the like, throughout the Peninsula. The inevitable result of the combination of large African movements into urban areas and inadequate provision of housing was to produce shortages, amounting to over 100,000 units by the mid-1990s. Since that time, governments at national and local levels have enacted a great deal of legislation to try to handle the problem. Nonetheless, many thousands of people lack decent housing. At the same time, the South African government has limited sources and a large variety of needs, stemming from the AIDS crisis, pervasive unemployment (about $40 \%$ ), and persistent, pervasive poverty.

\section{B. Grootboom and Wallacedene}

The Grootboom case was brought by 900 plaintiffs, of whom 510 were children. For a long period, the plaintiffs lived in an informal squatter settlement named Wallacedene. Most of the people there were desperately poor. All of them lived in shacks, without water, sewage, or refuse removal services. Only 5\% of the shacks had electricity. The named plaintiff, Irene Grootboom, lived with her family and that of her sister in a shack of about twenty square meters.

Many of those at the Wallacedene settlement had applied for low-cost housing from the municipality. They were placed on the waiting list, where they remained for a number of years. In late 1998, they became frustrated by the intolerable conditions at Wallacedene. They moved out and put up shacks and shelters on vacant land that was

\footnotetext{
${ }^{9}$ An exception is Hungary. See Andras Sajo, How the Rule of Law Killed Hungarian Welfare Reform, 5 Eastern European Constitutional Review 31 (1996). Here we'll obviously need the full reference ${ }^{10}$ I draw here from the Grootboom opinion.
} 
privately owned and earmarked for formal low-cost housing. A few months later, the owner obtained an ejectment order against them. But Grootboom and others refused to leave, contending that their former sites were now occupied and that there was nowhere else to go. Eventually they were forcibly evicted, with their homes burnt and bulldozed. Their possessions were destroyed. At this point they found shelter on a sports field in Wallacedene, under temporary structures consisting of plastic sheets. It was at this stage that they contended that their constitutional rights had been violated. It is worthwhile to pause over the nature of human existence for those at Wallacedene. For them, insecurity was a fact of daily life. It should not be controversial to say that the status of citizenship is badly compromised for people in such conditions.

\section{The Constitution}

Two provisions were of central importance to the plaintiffs' claim. The first is section 26, which provides:

"26(1) Everyone has the right to have access to adequate housing.

(2) The State must take reasonable legislative and other measures, within its available resources, to achieve the progressive realization of this right

(3) No one may be evicted from their home, or have their home demolished, without an order of court made after considering all the relevant circumstances . No legislation may permit arbitrary evictions."

The second was section 28(1)(c), limited to children. That section reads:

" 28 Every child has the right $-\ldots$

(b) to family care or parental care, or to appropriate alternative care when removed from the family environment:

(c) to basic nutrition, shelter, basic health care services and social services."

At the outset several points should be made about these sections. First, section 26(3) imposes a duty on the private sector, not only on government. Under this section, it is unconstitutional for a private person to evict another private person, or to demolish a home, without judicial permission. From the constitutional point of view, this is a striking innovation, for constitutions do not typically impose obligations on private landlords. From the standpoint of economic policy, it also raises several interesting questions. Obviously the goal of section 26(3) is to ensure that poor people continue to have housing; but the creation of a kind of property right in continued occupancy is likely to have some unintended bad consequences. If it is difficult to evict people, landlords will have a decreased incentive to provide housing in the first instance. The result might be a diminished stock of private housing. Another result might be extensive private screening of prospective tenants, since landlords will be entirely aware that once a tenancy is allowed, it will be very difficult to terminate it. The extent of these effects is of course an empirical question.

Do the following pages confuse sections 26 and 28 ? I indicated all the specific spots where I think it should be changed. THANKS! 
For purposes of constitutional interpretation, the largest puzzle has to do with the relationship between sections 26 and 28. It would be possible to read section 28 as giving children unqualified rights to various goods - ensuring that children have those goods even if resources are scarce. On this view, the government has an absolute obligation to ensure that children eat, are housed, and have health care and social services. Under this interpretation, section 26 creates as qualified right for everyone ("progressive realization") whereas section 28 requires an unqualified right for children in particular. Whether or not it is correct, this is a textually plausible reading.

The lower court proceeded in exactly this way, holding that section 28 creates a freestanding, absolute right, on the part of children, to the protections thus mentioned. On this interpretation, the rights are not qualified by "available resources" or by the "progressive realization" clause. Perhaps children are given, by that clause, two sets of rights: first to the care of adults, preferably parents; second to state support of basic needs.

\section{Grootboom in the Constitutional Court}

In Grootboom, the Constitutional Court rejected this interpretation of section 28 . At the same time, it held that section 26 imposes a judicially enforceable duty on government; that what is required in "reasonableness"; and that the plaintiffs" constitutional rights had been violated, because of the absence of a program to ensure provide "temporary relief" for those without shelter. In short, the Court held that the Constitution required not only a long-term plan to provide low-income shelter, but also a system to ensure short-term help for people who had no place to live. I believe that this is the first time that the high Court of any nation has issued a ruling of this general sort. What is most striking about that ruling is the distinctive and novel approach to socioeconomic rights, requiring not shelter for everyone, but sensible priority-setting, with particular attention to the plight of those who are neediest. I will say more by way of evaluation below; let us begin by tracing the Court's explanation of its decision.

\section{A. Section 26}

1. A note from international law. The movement for socio-economic rights cannot be understood without reference to international law, which firmly recognizes such rights, and which seems to put the weight of international opinion behind them. Hence the Court began by emphasizing the significant background provided by the International Covenant on Economic, Social, and Cultural Rights (a covenant signed but not yet ratified by South Africa).

Section 11.1 of the Covenant provides that the parties "recognize the right of everyone to an adequate standard of living for himself and his family, including adequate food, clothing and housing, and to the continuous improvement of living conditions." Hence the "parties will take appropriate steps to ensure the realization of this right . .." A more general provision of the Covenant, applicable to all relevant rights, makes a promise "to take steps . . . to the maximum of its available resources, with a view to 
achieving progressively the full realization of the rights recognized in the Covenant by all appropriate means, including particularly the adoption of legislative measures.", 11

But what does this mean? The United Nations Committee on Economic, Social and Cultural Rights is entrusted with monitoring the performance of states under the Covenant. In its interpretive comments, the Committee urges that states face a "minimum core obligation," consisting of a duty to "ensure the satisfaction of, at the very least, minimum essential levels of each of the rights." The Constitutional Court referred to this idea with some interest, suggesting the possibility of "minimum core obligations" imposed by section 26. But in the Court's view, that idea had many problems, because judicial enforcement would require a great deal of information to be placed before the court, in order to "determine the minimum core in any given context." In this case, sufficient information was lacking, and in any event the Court thought that it would not be necessary to define the minimum core in order to assess Grootboom's complaint.

2. Text and context. The Court's more specific analysis of section 26 began with an emphasis on the fact that all people have a right, not to shelter regardless of financial constraints, but to legislative and other measures designed to achieve "the progressive realization of this right." At the same time, the state, and "all other entities and persons," are constitutionally required "to desist from preventing or impairing the right of access to adequate housing." By itself this idea is quite ambiguous; what counts as prevention or impairment?

The Court explained that to implement the right, the state faced two kinds of duties. With respect to "those who can afford to pay for adequate housing," the state's duty is to "unlock[] the system, providing access to housing stock and a legislative framework to facilitate self-built houses through planning laws and access to finance." What is most striking here is the Court's emphasis on the "unlocking" role of the Constitution. On one interpretation, at least, the state is under a duty to ban a system of monopoly in housing to create market s sufficiently flexible to provide housing to those who can pay for it. But it is not clear that this is all, or even most, of what the Court had in mind. The idea of "planning laws" and "access to finance" might be taken to mean something other than, or in addition to, a competitive housing market. But it is certainly worth noticing that the analysis of a duty for "those who can afford to pay" operates along its own separate track, requiring a kind of open housing market for those with the resources to participate.

For poor people, of course, the state's obligation is different. Here the constitutional duty might be discharged through "programmes to provide adequate social assistance to those who are otherwise unable to support themselves and their dependents." In this case, the central issue was whether the government had created "reasonable" measures to ensure progressive realization of the right. The Court concluded that it had not, notwithstanding the extensive public apparatus to facilitate access to housing. The reason for this conclusion was simple: "there is no express provision to facilitate access to temporary relief for people who have no access to land, no roof over their heads, for people who are living in intolerable conditions and for people who are in crisis because

${ }^{11}$ Article 2.1 
of natural disasters such as floods or fires, or because their homes are under threat of demolition."

The Court acknowledged that it would be acceptable not to have a provision for those in desperate need "if the nationwide housing programme would result in affordable houses for most people within a reasonably short time." Note that "most people" does not mean all people; hence the clear implication is that a deprivation of housing, for some, would not necessarily be unreasonable or inconsistent with the constitutional plan. In this respect, the constitutional right involved the creation of a system of a certain kind rather than the creation of fully individual protections. But under the existing governmental program at the national level, it could not be said that "most people" would have "affordable houses" within a reasonably short time. Hence the nation's housing program is constitutionally unacceptable insofar as "it fails to recognize that the state must provide for relief for those in desperate need. . . It is essential that a reasonable part of the national housing budget be devoted to this, but the precise allocation is for the national government to decide in the first instance."

The Court also acknowledged that the constitutional obligation might be adequately carried out at the local level and that the local government, Cape Metro, had put in place its own land programme specifically to deal with desperate needs. But that programme had not been implemented, in large part because of an absence of adequate budgetary support from the national government. "Recognition of such needs in the nationwide housing programme requires" the national government "to plan, budget and monitor the fulfillment of immediate needs and the management of crises. This shall ensure that a significant number of desperate people in need are afforded relief, though not all of them need receive it immediately."

In the Court's view, the Constitution did not create a right to "shelter or housing immediately upon demand." But it did create a right to a "coherent, co-ordinated programme designed to meet" constitutional obligations. The obligation of the state was therefore to create such a program, including reasonable measures specifically designed "to provide relief for people who have no access to land, no roof over their heads, and who are living in intolerable conditions or crisis situations." It is here that we can find a novel, distinctive, and promising approach to a democratic constitution's socio-economic rights, an issue that I take up in more detail below.

\section{B. Section 28}

So much for Section 26 . What of Section 28 , which, it might be recalled, was understood by the lower court to create an absolute right to shelter for children? In brief, the Court refused to interpret section 28 in this way. Instead it understood section 28 to add little to the basic requirements of section 26?. In the Court's view, section 28 creates no independent socio-economic rights. This was an exceedingly narrow reading of section 28 , evidently a product of pragmatic considerations. The Court's responsiveness to those pragmatic considerations is itself noteworthy, especially insofar as it suggests judicial reluctance to intrude excessively into priority-setting at the democratic level. 
The Court's central holding was that with respect to children, the obligation to provide shelter and the like "is imposed primarily on parents and family, and only alternatively on the state." What this means is that when children are removed from their parents, the state must protect the specified rights by, for example, ensuring that children are housed and fed. But section 28 "does not create any primary state obligation to provide shelter on demand to parents and their children if children are being cared for by their parents or families."

To be sure, the state has some constitutional duty to children under the care of their parents and families. The state "must provide the legal and administrative infrastructure necessary to ensure" compliance with section 28 , through, for example, "passing laws and creating enforcement mechanisms for the maintenance of children, their protection from maltreatment, abuse, neglect or degradation." The state is also obliged to comply with the various independent protections of socio-economic rights. But section 26 created no freestanding obligation for the state to shelter children within the care of their parents. Since the children in Grootboom were being cared for by their parents, the state was not obliged to shelter them "in terms of section 28(1)."

At first glance, this is a puzzling reading of section 28(1), hardly foreordained by the text of the provision. Apparently the Court was led to that reading by what it saw as the "anomalous result" of giving those with children "a direct and enforceable right to housing" under that section, while depriving those "who have none or whose children are adult." This would be anomalous because it would allow parents to have special access to shelter if and because they had children. In any case a holding to this effect would make children into "stepping stones to housing for their parents." But would this really be so anomalous? It might seem to make sense to say that children should have a particular priority here - that their right should be more absolute - and hence that adults with children would have a preferred position. Why would that view be especially peculiar?

The Court also expressed a stronger concern. If children were taken to have an absolute right to shelter, the document's limitations on socio-economic rights would be quite undone. The "carefully constructed constitutional scheme for progressive realization of socio-economic rights would make little sense if it could be trumped in every case by the rights of children." Here, I think, is the heart of the Court's skepticism about the idea that section 28 should be taken to create absolute rights. If section 28 were so understood, it would trump even reasonable priority-setting, thus disallowing the state from deciding that in view of sharply limited resources, certain needs were even more pressing.

\section{Evaluation}

What I will urge here is that the approach of the South African Constitutional Court answers a number of questions about the proper relationship among socioeconomic rights, constitutional law, and democratic deliberation. There should be little 
question that people who live in desperate conditions cannot live good lives. People who live in such conditions are also unable to enjoy the status of citizenship.

On the other hand, legislatures in poor nations, and perhaps in less poor ones, cannot easily ensure that everyone lives in decent conditions. An especially plausible concern with socio-economic rights is the difficulty, for courts, of steering a middle course between two straightforward positions: (a) the socio-economic rights are nonjusticiable and (b) the socio-economic rights create an absolute duty, on government's part, to ensure protection for everyone who needs them. The second position is of course the standard approach to most constitutional rights. If the government has violated someone's right to free speech, or to freedom of religion, it does not matter that the rights of most people, or almost everyone else, have been respected. This sentence needs completion.

As I have emphasized, however, all rights have costs. ${ }^{12}$ The right to free speech, or for that matter to freedom from police abuse, will not be protected unless taxpayers are willing to fund a judicial system willing and able to protect that right and that freedom. In fact a system committed to free speech is also likely to require taxpayer resources to be devoted to keeping open certain arenas where speech can occur, such as streets and parks. In protecting the most conventional rights, the government must engage in some form of priority-setting. But when cases go to court, conventional rights are and can be fully protected at the individual level, and not merely through the creation of some kind of "reasonable" overall system for protection. The existence of a reasonable overall system for protecting free speech rights is not defense to a claim that, in a particular case, a right to free speech has been violated.

By their very nature, socio-economic rights are different on this count, certainly in the light of the "progressive realization" clause. No one thinks that every individual [Should it be "everyone" or "every individual"?] has an enforceable right to full protection of the interests at stake. In these circumstances it is difficult indeed to find an approach that avoids two unappealing courses: creation of fully enforceable individual rights or a conclusion of complete nonjusticiability. The only alternative to these extremes is an approach to public law that is generally unfamiliar in constitutional law but that is the ordinary material of administrative law, governing judicial control of administrative agencies: a requirement of reasoned judgment, including reasonable priority-setting.

In a typical administrative law case, an agency is faced with a burden of explanation. It must show why it has adopted the program that it has chosen; it must account for its failure to adopt a program of a different sort. For courts, a special attraction of this position is that it protects against administrative arbitrariness while also recognizes the democratic pedigree of the agency and the simple fact of limited resources. If an agency has allocated resources in a rational way, it has acted lawfully.

\footnotetext{
${ }^{12}$ See Stephen Holmes and Cass R. Sunstein, The Cost of Rights (1999).
} 
What the South African Constitution Court has basically done is to adopt an administrative law model of socio-economic rights. Courts using that model are hardly unwilling to invalidate an agency's choices as arbitrary. That, in effect, is what the Constitutional Court did in Grootboom. The Court required government to develop, and fund, a program by which a large number of poor people are given access to emergency housing. What the Court call for is some sort of reasonable plan, designed to ensure that relief will be forthcoming to a significant percentage of poor people. On this view, the Constitution constrains government, not by ensuring that everyone receives shelter, but by requiring government to devote more resources than it otherwise would to the problem of insufficient housing for the poor. More particularly, the Court requires government to maintain a plan for emergency relief for those who need it. This is the particular gap found unacceptable in Grootboom.

But there is a twist here. For those whose socio-economic rights are violated, the real problem is one of government inaction - a failure to implement a program of the sort that, in the view of some, the Constitution requires. The plaintiffs in Grootboom were seeking government action that had not, to that point, been forthcoming, in the particular form of a right to emergency relief. Hence the Grootboom Court's approach is most closely connected to a subset of administrative law principles, involving judicial review of inaction by government agencies. In cases of this kind, everyone knows that the agency faces a resource constraint and that in the face of a limited budget, any reasonable priority-setting will be valid and perhaps even free from judicial review. At the same time, there should be a duty of reasonableness in priority-setting, and an agency decision that rejects a statutory judgment, or that does not take statutory goals sufficiently seriously, should be held invalid. In the constitutional context, this is what the South African Court ruled in Grootboom.

The broader point here is that a constitutional right to shelter, or to food, can strengthen the hand of those who might be unable to make much progress in the political arena, perhaps because they are unsympathetic figures, perhaps because they are disorganized and lack political power. A socio-economic guarantee can have an enduring function. It can do so in part by promoting a certain kind of deliberation, not by preempting it, as a result of directing political attention to interests that would otherwise be disregarded in ordinary political life.

\section{Conclusion}

Should constitutions protect social and economic rights? It is certainly relevant that if basic needs are not met, people cannot really enjoy the status of citizens. A right to minimal social and economic guarantees can be justified, not only on the ground that people in desperate conditions will not have good lives, but also on the ground that democracy requires a certain independence and security for all citizens. But there are many complexities here. A government might attempt to meet people's needs in multiple ways, perhaps by creating incentives to ensure that people will help themselves, rather than by looking to government. Perhaps there is no special need for constitutional safeguards here; perhaps this is an issue that can be settled democratically. In any case 
social and economic guarantees threaten to put courts in a role for which they are quite ill-suited. While modern constitutions tend to protect those guarantees, we can understand the judgment that, in some nations, they would create more trouble than they are worth.

In Grootboom, the Constitutional Court of South Africa was confronted, for the first time, with the question of how, exactly, courts should protect socio-economic rights. The Court's approach suggests, also for the first time, the possibility of providing that protection in a way that is respectful of democratic prerogatives and the simple fact of limited budgets.

In making clear that the socio-economic rights are not given to individuals as such, the Court was at pains to say that the right to housing is not absolute. [Shouldn't it be "even children's right to housing"? with regards to adults, the constitution is explicit that these rights are not absolute. -- stet] This suggestion underlies the narrow interpretation of the provision involving children and also the Court's unambiguous suggestion that the state need not provide housing for everyone who needs it. What the constitutional right requires is not housing on demand, but a reasonable program for ensuring access to housing for poor people, including some kind of program for ensuring emergency relief. This approach ensures respect for sensible priority-setting, and close attention to particular needs, without displacing democratic judgments about how to set priorities. This is now the prevailing approach to the constitutional law of socio-economic rights in South Africa.

Of course the approach leaves many issues unresolved. Suppose that the government ensured a certain level of funding for a program of emergency relief; suppose too that the specified level is challenged as insufficient. The Court's decision suggests that whatever amount allocated must be shown to be "reasonable"; but what are the standards are resolving a dispute about that issue? The deeper problem is that any allocations of resources for providing shelter will prevent resources from going elsewhere - for example, for AIDS treatment and prevention, for unemployment compensation, for food, for basic income support. Undoubtedly the Constitutional Court will listen carefully to government claims that resources not devoted to housing are being used elsewhere. Undoubtedly those claims will be stronger if they suggest that some or all of the resources are being used to protect socio-economic rights of a different sort.

What is most important, however, is the Constitutional Court's adoption of a novel and highly promising approach to judicial protection of socio-economic rights. The ultimate effects of the approach remain to be seen. But by requiring reasonable programs, with careful attention to limited budgets, the Court has suggested the possibility of assessing claims of constitutional violations without at the same time requiring more than existing resources will allow. And in so doing, the Court has provided the most convincing rebuttal yet to those who have claimed, in the abstract quite plausibly, that judicial protection of socio-economic rights could not possibly be a good idea. We now have reason to believe that a democratic constitution, even in a poor nation, is able to protect those rights, and to do so without placing an undue strain on judicial capacities. 
Readers with comments should address them to:

Cass R. Sunstein

Karl N. Llewellyn Distinguished Service Professor of Jurisprudence University of Chicago Law School

1111 East 60th Street

Chicago, IL 60637

773-702-9498

E-mail: csunstei@midway.uchicago.edu 


\section{Chicago Working Papers in Law and Economics}

(Second Series)

1. William M. Landes, Copyright Protection of Letters, Diaries and Other Unpublished Works: An Economic Approach (July 1991).

2. Richard A. Epstein, The Path to The T.J. Hooper: The Theory and History of Custom in the Law of Tort (August 1991).

3. Cass R. Sunstein, On Property and Constitutionalism (September 1991).

4. Richard A. Posner, Blackmail, Privacy, and Freedom of Contract (February 1992).

5. Randal C. Picker, Security Interests, Misbehavior, and Common Pools (February 1992).

6. Tomas J. Philipson \& Richard A. Posner, Optimal Regulation of AIDS (April 1992).

7. Douglas G. Baird, Revisiting Auctions in Chapter 11 (April 1992).

8. William M. Landes, Sequential versus Unitary Trials: An Economic Analysis (July 1992).

9. William M. Landes \& Richard A. Posner, The Influence of Economics on Law: A Quantitative Study (August 1992).

10. Alan O. Sykes, The Welfare Economics of Immigration Law: A Theoretical Survey With An Analysis of U.S. Policy (September 1992).

11. Douglas G. Baird, 1992 Katz Lecture: Reconstructing Contracts (November 1992).

12. Gary S. Becker, The Economic Way of Looking at Life (January 1993).

13. J. Mark Ramseyer, Credibly Committing to Efficiency Wages: Cotton Spinning Cartels in Imperial Japan (March 1993).

14. Cass R. Sunstein, Endogenous Preferences, Environmental Law (April 1993).

15. Richard A. Posner, What Do Judges and Justices Maximize? (The Same Thing Everyone Else Does) (April 1993).

16. Lucian Arye Bebchuk and Randal C. Picker, Bankruptcy Rules, Managerial Entrenchment, and Firm-Specific Human Capital (August 1993).

17. J. Mark Ramseyer, Explicit Reasons for Implicit Contracts: The Legal Logic to the Japanese Main Bank System (August 1993).

18. William M. Landes and Richard A. Posner, The Economics of Anticipatory Adjudication (September 1993).

19. Kenneth W. Dam, The Economic Underpinnings of Patent Law (September 1993).

20. Alan O. Sykes, An Introduction to Regression Analysis (October 1993).

21. Richard A. Epstein, The Ubiquity of the Benefit Principle (March 1994).

22. Randal C. Picker, An Introduction to Game Theory and the Law (June 1994).

23. William M. Landes, Counterclaims: An Economic Analysis (June 1994).

24. J. Mark Ramseyer, The Market for Children: Evidence from Early Modern Japan (August 1994).

25. Robert H. Gertner and Geoffrey P. Miller, Settlement Escrows (August 1994).

26. Kenneth W. Dam, Some Economic Considerations in the Intellectual Property Protection of Software (August 1994).

27. Cass R. Sunstein, Rules and Rulelessness, (October 1994).

28. David Friedman, More Justice for Less Money: A Step Beyond Cimino (December 1994). 
29. Daniel Shaviro, Budget Deficits and the Intergenerational Distribution of Lifetime Consumption (January 1995).

30. Douglas G. Baird, The Law and Economics of Contract Damages (February 1995).

31. Daniel Kessler, Thomas Meites, and Geoffrey P. Miller, Explaining Deviations from the Fifty Percent Rule: A Multimodal Approach to the Selection of Cases for Litigation (March 1995).

32. Geoffrey P. Miller, Das Kapital: Solvency Regulation of the American Business Enterprise (April 1995).

33. Richard Craswell, Freedom of Contract (August 1995).

34. J. Mark Ramseyer, Public Choice (November 1995).

35. Kenneth W. Dam, Intellectual Property in an Age of Software and Biotechnology (November 1995).

36. Cass R. Sunstein, Social Norms and Social Roles (January 1996).

37. J. Mark Ramseyer and Eric B. Rasmusen, Judicial Independence in Civil Law Regimes: Econometrics from Japan (January 1996).

38. Richard A. Epstein, Transaction Costs and Property Rights: Or Do Good Fences Make Good Neighbors? (March 1996).

39. Cass R. Sunstein, The Cost-Benefit State (May 1996).

40. William M. Landes and Richard A. Posner, The Economics of Legal Disputes Over the Ownership of Works of Art and Other Collectibles (July 1996).

41. John R. Lott, Jr. and David B. Mustard, Crime, Deterrence, and Right-to-Carry Concealed Handguns (August 1996).

42. Cass R. Sunstein, Health-Health Tradeoffs (September 1996).

43. G. Baird, The Hidden Virtues of Chapter 11: An Overview of the Law and Economics of Financially Distressed Firms (March 1997).

44. Richard A. Posner, Community, Wealth, and Equality (March 1997).

45. William M. Landes, The Art of Law and Economics: An Autobiographical Essay (March 1997).

46. Cass R. Sunstein, Behavioral Analysis of Law (April 1997).

47. John R. Lott, Jr. and Kermit Daniel, Term Limits and Electoral Competitiveness: Evidence from California's State Legislative Races (May 1997).

48. Randal C. Picker, Simple Games in a Complex World: A Generative Approach to the Adoption of Norms (June 1997).

49. Richard A. Epstein, Contracts Small and Contracts Large: Contract Law through the Lens of Laissez-Faire (August 1997).

50. Cass R. Sunstein, Daniel Kahneman, and David Schkade, Assessing Punitive Damages (with Notes on Cognition and Valuation in Law) (December 1997).

51. William M. Landes, Lawrence Lessig, and Michael E. Solimine, Judicial Influence: A Citation Analysis of Federal Courts of Appeals Judges (January 1998).

52. John R. Lott, Jr., A Simple Explanation for Why Campaign Expenditures are Increasing: The Government is Getting Bigger (February 1998).

53. Richard A. Posner, Values and Consequences: An Introduction to Economic Analysis of Law (March 1998). 
54. Denise DiPasquale and Edward L. Glaeser, Incentives and Social Capital: Are Homeowners Better Citizens? (April 1998).

55. Christine Jolls, Cass R. Sunstein, and Richard Thaler, A Behavioral Approach to Law and Economics (May 1998).

56. John R. Lott, Jr., Does a Helping Hand Put Others At Risk?: Affirmative Action, Police Departments, and Crime (May 1998).

57. Cass R. Sunstein and Edna Ullmann-Margalit, Second-Order Decisions (June 1998).

58. Jonathan M. Karpoff and John R. Lott, Jr., Punitive Damages: Their Determinants, Effects on Firm Value, and the Impact of Supreme Court and Congressional Attempts to Limit Awards (July 1998).

59. Kenneth W. Dam, Self-Help in the Digital Jungle (August 1998).

60. John R. Lott, Jr., How Dramatically Did Women's Suffrage Change the Size and Scope of Government? (September 1998)

61. Kevin A. Kordana and Eric A. Posner, A Positive Theory of Chapter 11 (October 1998)

62. David A. Weisbach, Line Drawing, Doctrine, and Efficiency in the Tax Law (November 1998)

63. Jack L. Goldsmith and Eric A. Posner, A Theory of Customary International Law (November 1998)

64. John R. Lott, Jr., Public Schooling, Indoctrination, and Totalitarianism (December 1998)

65. Cass R. Sunstein, Private Broadcasters and the Public Interest: Notes Toward A “Third Way" (January 1999)

66. Richard A. Posner, An Economic Approach to the Law of Evidence (February 1999)

67. Yannis Bakos, Erik Brynjolfsson, Douglas Lichtman, Shared Information Goods (February 1999)

68. Kenneth W. Dam, Intellectual Property and the Academic Enterprise (February 1999)

69. Gertrud M. Fremling and Richard A. Posner, Status Signaling and the Law, with Particular Application to Sexual Harassment (March 1999)

70. Cass R. Sunstein, Must Formalism Be Defended Empirically? (March 1999)

71. Jonathan M. Karpoff, John R. Lott, Jr., and Graeme Rankine, Environmental Violations, Legal Penalties, and Reputation Costs (March 1999)

72. Matthew D. Adler and Eric A. Posner, Rethinking Cost-Benefit Analysis (April 1999)

73. John R. Lott, Jr. and William M. Landes, Multiple Victim Public Shooting, Bombings, and Right-to-Carry Concealed Handgun Laws: Contrasting Private and Public Law Enforcement (April 1999)

74. Lisa Bernstein, The Questionable Empirical Basis of Article 2's Incorporation Strategy: A Preliminary Study (May 1999)

75. Richard A. Epstein, Deconstructing Privacy: and Putting It Back Together Again (May 1999)

76. William M. Landes, Winning the Art Lottery: The Economic Returns to the Ganz Collection (May 1999)

77. Cass R. Sunstein, David Schkade, and Daniel Kahneman, Do People Want Optimal Deterrence? (June 1999) 
78. Tomas J. Philipson and Richard A. Posner, The Long-Run Growth in Obesity as a Function of Technological Change (June 1999)

79. David A. Weisbach, Ironing Out the Flat Tax (August 1999)

80. Eric A. Posner, A Theory of Contract Law under Conditions of Radical Judicial Error (August 1999)

81. David Schkade, Cass R. Sunstein, and Daniel Kahneman, Are Juries Less Erratic than Individuals? Deliberation, Polarization, and Punitive Damages (September 1999)

82. Cass R. Sunstein, Nondelegation Canons (September 1999)

83. Richard A. Posner, The Theory and Practice of Citations Analysis, with Special Reference to Law and Economics (September 1999)

84. Randal C. Picker, Regulating Network Industries: A Look at Intel (October 1999)

85. Cass R. Sunstein, Cognition and Cost-Benefit Analysis (October 1999)

86. Douglas G. Baird and Edward R. Morrison, Optimal Timing and Legal Decisionmaking: The Case of the Liquidation Decision in Bankruptcy (October 1999)

87. Gertrud M. Fremling and Richard A. Posner, Market Signaling of Personal Characteristics (November 1999)

88. Matthew D. Adler and Eric A. Posner, Implementing Cost-Benefit Analysis When Preferences Are Distorted (November 1999)

89. Richard A. Posner, Orwell versus Huxley: Economics, Technology, Privacy, and Satire (November 1999)

90. David A. Weisbach, Should the Tax Law Require Current Accrual of Interest on Derivative Financial Instruments? (December 1999)

91. Cass R. Sunstein, The Law of Group Polarization (December 1999)

92. Eric A. Posner, Agency Models in Law and Economics (January 2000)

93. Karen Eggleston, Eric A. Posner, and Richard Zeckhauser, Simplicity and Complexity in Contracts (January 2000)

94. Douglas G. Baird and Robert K. Rasmussen, Boyd's Legacy and Blackstone's Ghost (February 2000)

95. David Schkade, Cass R. Sunstein, Daniel Kahneman, Deliberating about Dollars: The Severity Shift (February 2000)

96. Richard A. Posner and Eric B. Rasmusen, Creating and Enforcing Norms, with Special Reference to Sanctions (March 2000)

97. Douglas Lichtman, Property Rights in Emerging Platform Technologies (April 2000)

98. Cass R. Sunstein and Edna Ullmann-Margalit, Solidarity in Consumption (May 2000)

99. David A. Weisbach, An Economic Analysis of Anti-Tax Avoidance Laws (May 2000)

100. Cass R. Sunstein, Human Behavior and the Law of Work (June 2000)

101. William M. Landes and Richard A. Posner, Harmless Error (June 2000)

102. Robert H. Frank and Cass R. Sunstein, Cost-Benefit Analysis and Relative Position (August 2000)

103. Eric A. Posner, Law and the Emotions (September 2000)

104. Cass R. Sunstein, Cost-Benefit Default Principles (October 2000)

105. Jack Goldsmith and Alan Sykes, The Dormant Commerce Clause and the Internet (November 2000) 
106. Richard A. Posner, Antitrust in the New Economy (November 2000)

107. Douglas Lichtman, Scott Baker, and Kate Kraus, Strategic Disclosure in the Patent System (November 2000)

108. Jack L. Goldsmith and Eric A. Posner, Moral and Legal Rhetoric in International Relations: A Rational Choice Perspective (November 2000)

109. William Meadow and Cass R. Sunstein, Statistics, Not Experts (December 2000)

110. Saul Levmore, Conjunction and Aggregation (December 2000)

111. Saul Levmore, Puzzling Stock Options and Compensation Norms (December 2000)

112. Richard A. Epstein and Alan O. Sykes, The Assault on Managed Care: Vicarious Liability, Class Actions and the Patient's Bill of Rights (December 2000)

113. William M. Landes, Copyright, Borrowed Images and Appropriation Art: An Economic Approach (December 2000)

114. Cass R. Sunstein, Switching the Default Rule (January 2001)

115. George G. Triantis, Financial Contract Design in the World of Venture Capital (January 2001)

116. Jack Goldsmith, Statutory Foreign Affairs Preemption (February 2001)

117. Richard Hynes and Eric A. Posner, The Law and Economics of Consumer Finance (February 2001)

118. Cass R. Sunstein, Academic Fads and Fashions (with Special Reference to Law) (March 2001)

119. Eric A. Posner, Controlling Agencies with Cost-Benefit Analysis: A Positive Political Theory Perspective (April 2001)

120. Douglas G. Baird, Does Bogart Still Get Scale? Rights of Publicity in the Digital Age (April 2001)

121. Douglas G. Baird and Robert K. Rasmussen, Control Rights, Priority Rights and the Conceptual Foundations of Corporate Reorganization (April 2001)

122. David A. Weisbach, Ten Truths about Tax Shelters (May 2001)

123. William M. Landes, What Has the Visual Arts Rights Act of 1990 Accomplished? (May 2001)

124. Cass R. Sunstein, Social and Economic Rights? Lessons from South Africa (May 2001) 